\title{
ОЦНЮВАННЯ ЕФЕКТИВНОСТІ ВВЕДЕННЯ РЕЧОВИНИ У ВІДБИВНИЙ РОЗРЯД ЗА РАХУНОК РОЗПИЛЮВАННЯ МАТЕРІАЛУ КАТОДА
}

\author{
Ю.В. КОВТУН, Є.I. СКІБЕНКО, А.І. СКИБЕНКО, В.Б. ЮФЕРОВ
}

Національний науковий центр "Харківський фізико-технічний інститут" НАН України

УДК 533.915

(Вул. Академічна, 1, Харків 61108; e-mail: Ykovtun@kipt.kharkov. ua)

У роботі розглянуто процеси, пов'язані з введенням робочої речовини у плазму імпульсного відбивного розряду за рахунок розпилюючого механізму з метою створення густої багатокомпонентної газометалевої плазми. При цьому запропоновано розрахункову модель оцінки параметрів розпилюючого механізму, за рахунок якого потрібна робоча речовина надходить у розряд. Одержані дані задовільно узгоджуються з результатами експерименту.

\section{1. Вступ}

Відбивний розряд [1], відомий також як розряд Пеннінга, має багаторічну історію розвитку і дослідження. У даний час він широко використовується у різних галузях науки і техніки [2-7]. Так, наприклад, проведення досліджень процесу розпилювання різних матеріалів у плазмі відбивного розряду [5-7] пов'язане $з$ необхідністю визначення можливості їх використання у ролі конструкційних у термоядерному реакторі. Окремо варто виділити проблему введення робочої (що розділяється) речовини в робочий об'єм магніто-плазмового сепаратора на основі відбивного розряду [8] або якого-небудь іншого типу. Із літератури [9-12] відомо, що існує декілька підходів, які можуть бути використані для цих цілей, а саме: термічне випаровування [9], термічне випаровування 3 подальшою передіонізацією [10], термічне випаровування і введення речовини у вигляді надзвукового струменя [11], а також розпилювання речовини [12], що розділяється, де плазма створювалася за допомогою джерела на електронно-циклотронному резонанci, a речовину, що розділяється, у вигляді додатко- вої пластини під негативним потенціалом, вводили у плазму. Переважнішою є схема (пристрій) для введення робочої речовини з використанням відбивного розряду. У цьому випадку реалізується такий порядок: створення попередньої плазми та корпускулярне розпилення матеріалу катода, і надходження розпорошеної речовини у плазму з подальшою її іонізацією, що не вимагає додаткових пристроїв, як у роботі [12]. Як показує попередній досвід $[8,11,13-15]$, відбивний розряд є ефективним засобом створення багатокомпонентної газометалевої плазми, причому металева компонента плазми утворюється шляхом іонізації частинок матеріалу катода, що надходять у розряд шляхом його розпилення.

Проте детального розгляду процесу розпилення речовини катода і їі подальшої іонізації у відбивному розряді не проводили. Особливо важливим цей розгляд є для імпульсних пристроїв, для яких характерні часи утворення плазми менші від часу встановлення стаціонарної іонізаційної рівноваги. Пряме визначення кількості надходження у розряд важкої фракції багатокомпонентної плазми є вельми непростою справою, що вимагає при цьому достатньо значних матеріальних витрат. Тому вважається корисною і необхідною розробка методики кількісного оцінювання надходження важкої, що розпилюється, компоненти у розряд. Таким чином, метою даної роботи є розгляд процесів введення і іонізації речовини на початковій стадії утворення газометалевої густої плазми в імпульсному відбивному розряді за рахунок розпиленого механізму. При цьому вважається за необхідне вибір такої розрахункової моделі, у межах якої враховувалися б не тільки процеси, що приво- 


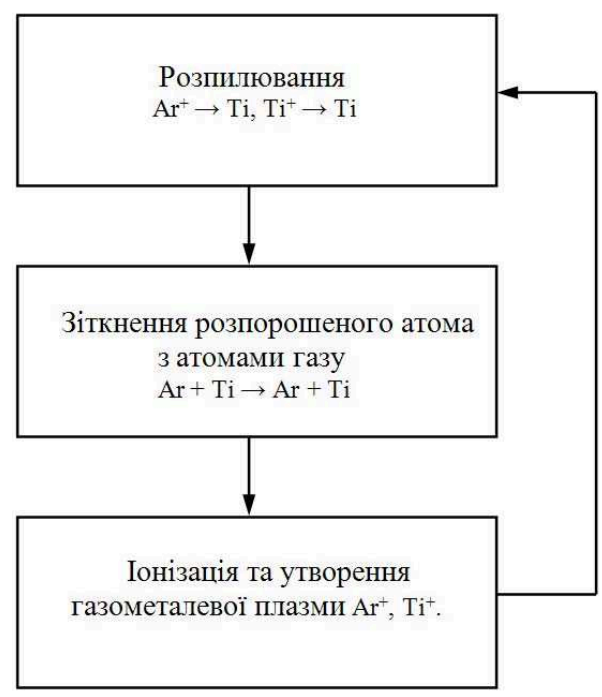

Рис. 1. Схема розрахункової моделі

дять до створення газометалевої плазми (розпилення та іонізація), а і відповідальні за рівномірне заповнення внутрішнього об'єму утримуючого магнітного поля, наприклад, пробкової конфігурації, плазмою і нейтральною речовиною протягом кінцевого відрізку часу. У запропонованій моделі, схему якої подано на рис. 1, з урахуванням основних етапів обчислення (розпилення, зіткнення розпорошеного атома з атомами газу, іонізація та утворення газометалевої плазми) треба розрахувати такі параметри: розпилювання - залежність коефіцієнта розпилювання від маси налітаючого іона, його енергії та кута падіння, а також повну кількість розпорошених частинок; зіткнення розпорошеного атома з атомами газу - енергетичний спектр і середню енергію розпорошених атомів, довжину вільного пробігу розпорошеного атома у газі, коефіцієнт і час дифузії; іонізацію та утворення газометалевої плазми - час та ступінь іонізації розпорошених атомів, процентний вміст іонів розпилюванного матеріалу у плазмі.

\section{2. Оцінювання параметрів розпилювального механізму}

Розгляд процесів розпилення та іонізації речовини на початковій стадії утворення газометалевої густої плазми в імпульсному відбивному розряді будемо проводити для типових експериментальних умов робіт [13, 14]: розрядна напруга $3,5-4 \mathrm{kB}$; запалювальний газ $\mathrm{Ar}$; матеріал катодів $\mathrm{Ti}$; часовий інтервал $\approx 100$ мкс, при якому досягається густина $\approx 2 \cdot 10^{19} \mathrm{M}^{-3}$. Стадія запалення розряду у даному випадку розглядатися не буде, оскільки такий розгляд проводили раніше, наприклад, у роботі [16]. Спершу розглянемо процеси, пов'язані з взаємодією плазми $з$ поверхнею твердого тіла.

Під час взаємодії плазми з поверхнею твердого тіла відбувається низка процесів [17], а саме: розпилення, емісія електронів при взаємодії частинок з поверхнею, проникнення, віддзеркалення і десорбція частинок, що стимулюється, зміна приповерхневого шару, зміна зарядового стану іонів, блістерінг та ін. Одним із основних процесів, що приводять до руйнування матеріалу катода i, відповідно, надходження його у плазму, є розпилювання. Основною характеристикою цього процесу є коефіцієнт розпилювання $Y$, залежний від заряду і маси налітаючого іона, його енергії, кута падіння, а також від матеріалу і температури мішені. Цей процес має енергетичний поріг розпилення. Зміна коефіцієнта розпилювання $Y$ від матеріалу мішені проявляється, по-перше, в його залежності від маси і атомного номера атомів мішені, по-друге, залежно від поверхневої енергії зв'язку атомів мішені $U_{s}$, яка, зазвичай, вважається такою ж як енергія сублімації, віднесена до одного атома. Залежність коефіцієнта розпилювання $Y(E)$ моноатомної речовини від енергії іонів при нормальному падінні можна виразити емпіричною формулою [18]:

$$
\begin{aligned}
& Y(E)=0,042 \frac{Q\left(Z_{2}\right) \alpha^{*}\left(M_{2} / M_{1}\right)}{U_{s}} \times \\
& \times \frac{S_{n}(E)}{1+\Gamma k_{e} \varepsilon^{0,3}}\left[1-\sqrt{\frac{E_{t h}}{E}}\right]^{s}, \text { атом } / \text { іон }
\end{aligned}
$$

де числовий множник в $\AA^{-2} ; E$ - енергія налітаючого іона, eB; $M_{1}$ і $M_{2}$ - відповідно маса налітаючого іона і атома мішені, а.о.м.; $E_{\mathrm{th}}-$ порогова енергія розпилювання, $\mathrm{eB} ; Q\left(Z_{2}\right)$ - безрозмірний параметр; $\alpha^{*}\left(M_{1} / M_{2}\right)$ - функція відношення мас, незалежна від енергї; $S_{n}(E)$ - перетин ядерного гальмування, $\mathrm{eBA}^{-2} /$ атом; $k_{e}$ - коефіцієнт електронного гальмування Ліндхарда; $\varepsilon$ - безрозмірна енергетична змінна; $s$ - показник ступеня, слабко залежний від матеріалу мішені; Г - фактор. Залежність коефіцієнта розпилювання для пар $\mathrm{Ar}^{+} \rightarrow \mathrm{Ti}$ та $\mathrm{Ti}^{+} \rightarrow \mathrm{Ti}$ розрахована за формулою (1), наведеною на рис. 2.

Як видно, коефіцієнт розпилювання для обох вибраних пар трохи відрізняється і для енергій налітаючих іонів 1-4 кеВ знаходиться у межах $0,73-1,44$. Величина порогової енергії розпилювання $E_{\mathrm{th}}$ для моделі [18] становить 28 еВ і 32 еВ, відповідно, для пари $\mathrm{Ar}^{+} \rightarrow \mathrm{Ti}$ та $\mathrm{Ti}^{+} \rightarrow \mathrm{Ti}$. У відбивному розряді згідно 


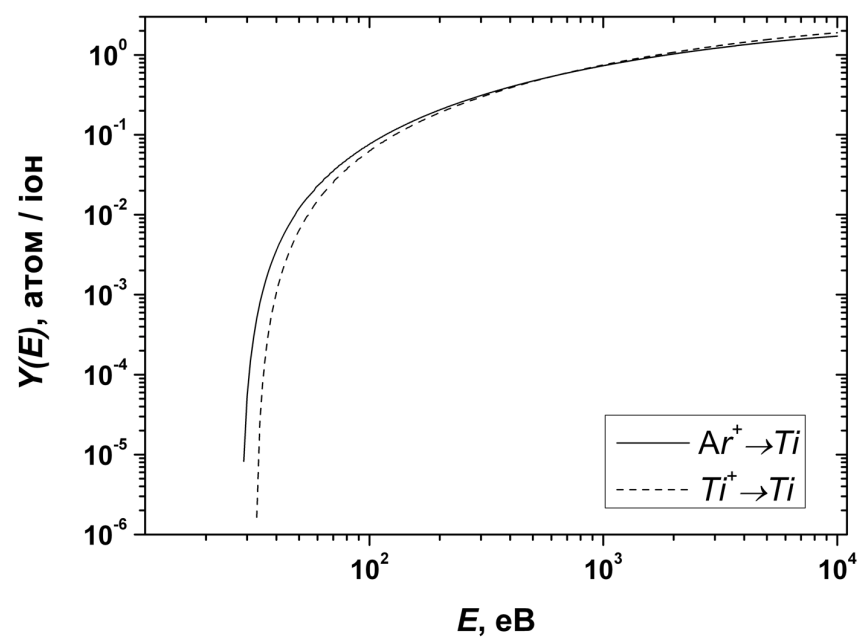

Рис. 2. Залежність коефіцієнта розпилювання від енергії налітаючих іонів різного сорту при нормальному падінні

із роботою [5] максимум функції розподілу іонів за енергіями знаходиться на рівні 0,8 - 0,85 від прикладеної напруги. У нашому випадку типова розрядна напруга становила від 3,5 до $4 \mathrm{kB}$, тобто енергія іонів у максимумі функції розподілу дорівнює $2,8-3,4$ кеВ. Тому для подальших розрахунків використовуватимемо даний діапазон енергій.

Як відомо, поверхня твердого тіла часто має достатньо розвинену структуру рельєфу, а взаємодія з іонними і плазмовими потоками викликає ті або інші зміни рельєфу. Залежно від параметрів потоку і умов на поверхні ці зміни виявляються як в розвитку, так і в згладжуванні рельєфу. Ефект згладжування, зазвичай, спостерігається або при енергіях іонів, нижчих за поріг розпилення, або при великих кутах падіння, коли коефіцієнт розпилювання менший, ніж при нормальному падінні [17]. У разі відбивного розряду, оскільки відбувається обертання плазми, кут падіння іона на поверхню катода може значно відрізнятися від 0, що, у свою чергу, приводить до зміни коефіцієнта розпилювання. Залежність коефіцієнта розпилювання від кута падіння іона $Y(\theta)$ виражається формулою [19]:

$Y(\theta)=Y(0) x^{f} \exp [-\Sigma(x-1)]$, атом/iон,

де $\theta-$ кут падіння; $x=1 / \cos \theta ; f$ та $\Sigma$ - параметри, які знаходяться з експерименту або розраховуються. Результати розрахунку залежності коефіцієнтів розпилювання від кута падіння іона $Y(\theta)$ за формулою 2 наведено на рис. 3. Як видно, кут, при якому спостерігається максимальний коефіцієнт розпилювання, дорівнює $\approx 73^{\circ}$, а коефіцієнт розпилювання зростає приблизно у 3 рази.

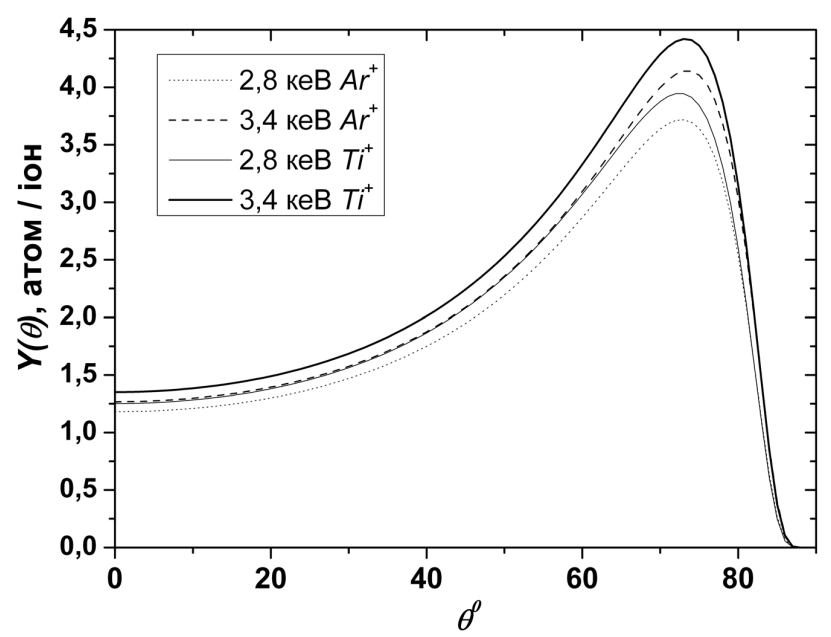

Рис. 3. Залежність коефіцієнта розпилювання від кута падіння налітаючого іона на мішень для різних енергій

Повна кількість розпорошених частинок за час $t 3$ поверхні катодів дорівнює:

$N_{\Sigma m}=\Gamma_{i} Y S_{\Sigma} t$, частинок,

де $S_{\Sigma}$ - сумарна площа катодів, що дорівнює 0,01571 $\mathrm{m}^{2} ; t$ - час, $\mathrm{c}, \Gamma_{i}-$ потік частинок на поверхню катодів, $\mathrm{M}^{-2} \cdot \mathrm{c}^{-1}$; який визначається так:

$\Gamma_{i}=N_{i} v_{s}, \mathrm{M}^{-2} \cdot \mathrm{c}^{-1}$,

де $N_{i}$ - густина іонів, $\mathrm{M}^{-3} ; v_{s}$ - іонно-звукова швидкість (швидкість іонного звуку), що визначається як:

$v_{s}=9,79 \cdot 10^{3}\left(Z T_{e} / M_{i}\right)^{1 / 2}, \mathrm{M} / \mathrm{c}$,

де $T_{e}$ - електронна температура, еВ; $M_{i}$ - маса іона, а.о.м.; $Z$ - заряд іона. Приймаємо масу іона рівною масі аргону $M_{i}=39,94$, температуру електронів $1-10$ еВ та отримуємо $v_{s}=(1,5-4,9) \cdot 10^{3} \mathrm{~m} / \mathrm{c}$.

Як зазначалося раніше у [14], часову залежність середньої густини газометалевої плазми можна розділити на три стадії: утворення, існування густої плазми і їі розпаду. Для оцінки $N_{\Sigma m}$ повної кількості розпорошених частинок на стадії утворення плазми приймемо зміну густини частинок у часі рівною експериментально отриманій у роботі [14], час $t \approx 100$ мкс, енергія іонів дорівнює 0,8-0,85 від прикладеної напруги. При цьому, залежно від коефіцієнта розпилювання, величина $N_{\Sigma m}$ лежить у діапазоні від $7,5 \cdot 10^{16}$ до $2,8 \cdot 10^{17}$ частинок. На стадії існування щільної плазми приймаємо середній коефіцієнт розпилювання, що дорівнює $0,02-0,26$, час $\sim 800$ мкс, отримуємо на цій стадії розряду $N_{\Sigma m} \sim 10^{17}-10^{18}$ частинок, 


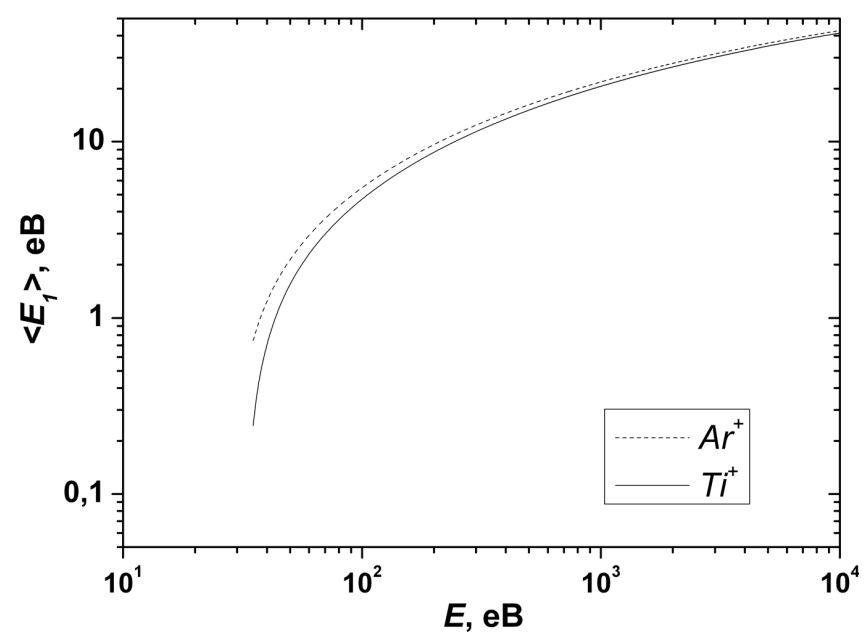

Рис. 4. Залежність середньої енергії атомів титану, що вилітають з мішені, від енергії налітаючих іонів

що знаходиться у згоді з експериментальними і розрахунковими результатами $N_{\Sigma m}=9,26 \cdot 10^{16}-8,5 \cdot 10^{17}$ роботи [15].

\section{3. Ефективність процесів іонізації розпорошених атомів і утворення газометалевої плазми}

Ефективність процесів захоплення розпорошених атомів у розряд і утворення газометалевої плазми залежить від двох процесів, а саме: дифузії і іонізації атомів у первинній плазмі. Розглянемо ці процеси детальніше.

Згідно з кінетичною теорією газів коефіцієнт дифузї дорівнює [20]:

$D=\frac{1}{3} \lambda v, \mathrm{~m}^{2} / \mathrm{c}$,

де $\lambda$ - середня довжина вільного пробігу, м; $v$ - швидкість, м/с. При цьому характерний час дифузії дорівнює часу виходу частинки на стінку:

$\tau_{D}=\frac{\Lambda^{2}}{D}, \mathrm{c}$,

де $\Lambda^{2}$ - характерна дифузійна довжина, у випадку циліндрової геометрії дорівнює:

$\frac{1}{\Lambda^{2}}=\left(\frac{2,4}{R}\right)^{2}+\left(\frac{\pi}{l}\right)^{2}$

де $R$ - радіус системи, м; $l$ - довжина системи, м. Для визначення залежності довжини вільного пробігу від енергії розпорошеного атома, що рухається у газі, атоми якого мають максвелівський розподіл за швидкостями, можна використовувати вираз, отриманий у роботі [21]:

$\lambda=\lambda_{0}\left[\left(1+\frac{1}{2 \omega}\right) \operatorname{erf}(\sqrt{\omega})+\frac{e^{-\omega}}{\sqrt{\pi \omega}}\right]^{-1}, \mathrm{M}$

$\omega=\frac{3}{2} \frac{E_{1}}{E_{g}} \frac{M_{g}}{M_{m}}$

де $E_{1}$ - енергія розпорошеного атома, eB; $E_{g}$ - середня енергія атома газу, $\mathrm{eB} ; M_{g}$ і $M_{m}$ - відповідно маса атома газу та розпорошеного атома, а.о.м.; $\lambda_{0}=1 / N \sigma, \sigma-$ ефективний переріз зіткнення, ${ }^{2} ; N-$ густина частинок газу, $\mathrm{M}^{-3}$. У процесі руху розпорошеного атома у газі (за рахунок зіткнень) відбувається релаксація енергї розпорошеного атома, при цьому середня енергія атомів $E_{F}$ на деякій відстані від поверхні, що розпилюється, може бути оцінена як [22]:

$E_{F}=\left(E_{0}-k T_{g}\right) \exp \left[n \ln \left(\frac{E_{f}}{E_{i}}\right)\right]+k T_{g}$,

де $E_{0}$ - первинна енергія розпорошеного атома, Дж; $k$ - стала Больцмана, Дж $/ \mathrm{K} ; T_{g}$ - температура газу, $\mathrm{K} ; E_{f} / E_{i}=\Delta E / E=2 M_{g} M_{m} /\left(M_{g}+M_{m}\right)^{2}-$ відношення енергії після і до зіткнення; $n$ - кількість зіткнень, що визначається як: $n=l_{1} P \sigma / k T_{g}$, де $l_{1}-$ довжина шляху, м; $P$ - тиск газу, Па. Для оцінювання $E_{F}$ приймемо $E_{0}=\left\langle E_{1}\right\rangle$, а $T_{g}=300 \mathrm{~K}$.

Середня енергія атомів, що вилітають із мішені, визначається так [23]:

$\left\langle E_{1}\right\rangle=2 U_{s} g(w)$

де $g(w)$ - функція, що визначається як:

$g(w)=\left(\ln (w)+\frac{2}{w}-\frac{1}{2 w^{2}}-\frac{3}{2}\right)\left(1-\frac{1}{w}\right)^{-2}$,

де $w=E / E_{\mathrm{th}}$. Результати розрахунку середньої енергії атомів титану наведено на рис. 4, а результати розрахунку величини $E_{F}$ від тиску газу подано на рис. 5. Варто відзначити, що зменшення енергї розпорошених атомів у процесі руху в газі (див. рис. 5) призведе до зменшення довжини пробігу атомів у газі, проте значний вплив відбудеться при наближенні енергії розпорошених атомів до теплової. Зіткнення розпорошених атомів з іонами газу, незважаючи на те, що транспортний переріз розсіювання не менше ніж на порядок більше газокінетичного, переважатимуть тільки при високих ступенях іонізації газу. 


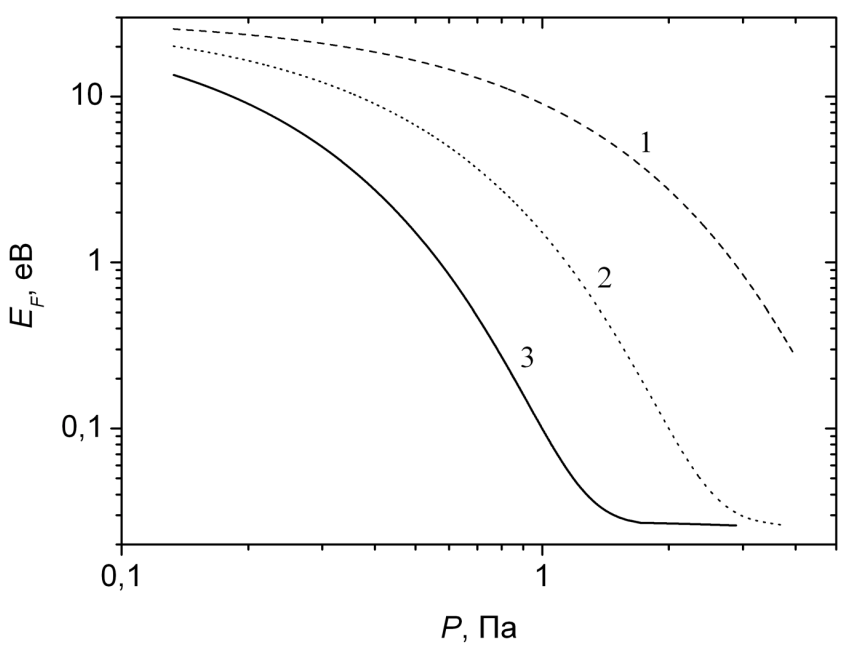

Рис. 5. Залежність середньої енергії розпорошених атомів титану від тиску аргону у розрядній камері для різних відстаней від поверхні, що розпилюється: 1 - 0,02 м; 2-0,05 м; 3-0,1 м

Енергетичний спектр розпорошених атомів описується формулою Томпсона [24], з урахуванням анізотропних ефектів і кута падіння іона він визначається так [25]:

$\Phi\left(E_{1}, \theta\right) \propto \frac{E_{1} \cos \theta}{\left(E_{1}+U_{s}\right)^{4}}\left(E_{1} \cos ^{2} \theta+U_{s}\right)$.

Використовуючи рівняння (6)-(10) і усереднюючи по функції розподілу розпорошених атомів від енергії залежно від кута падіння іонів, отримуємо середнє значення часу дифузії розпорошених атомів до стінки камери, яке наведено на рис. 6 (криві 6,7 ).

Одним із основних процесів, що приводять до іонізації атома, є іонізація електронним ударом, при цьому час іонізації дорівнює:

$\tau_{i}=\frac{1}{N_{e}\left\langle\sigma_{e} v_{e}\right\rangle}, \mathrm{c}$,

де $\left\langle\sigma_{e} v_{e}\right\rangle$ - швидкість іонізації атома електронним ударом [26], м³/c; $N_{e}$ - густина електронів, $\mathrm{m}^{-3}$. Додатковим механізмом іонізації атомів титану можуть служити процеси типу [27]: 1 - перезарядка іона на атомі (нерезонансна перезарядка): $X^{+}+Y \rightarrow X+$ $Y^{+}+\Delta E$ або $X^{+}+Y \rightarrow X+Y^{+*}+\Delta E$, де $\Delta E-$ дефект енергії процесу, що дорівнює різниці потенціалів іонізації або збудження обох частинок, що зіштовхуються, 2 - іонізація при зіткненні з метастабільним атомом, процес Пеннінга: $X^{*}+Y \rightarrow X+Y^{+}+e$. Згідно з роботою [28] швидкість перезарядки іона аргону на атомі титану $k_{\mathrm{CT}}=6,61 \cdot 10^{-15} \mathrm{~m}^{3} / \mathrm{c}$, пеннінгового

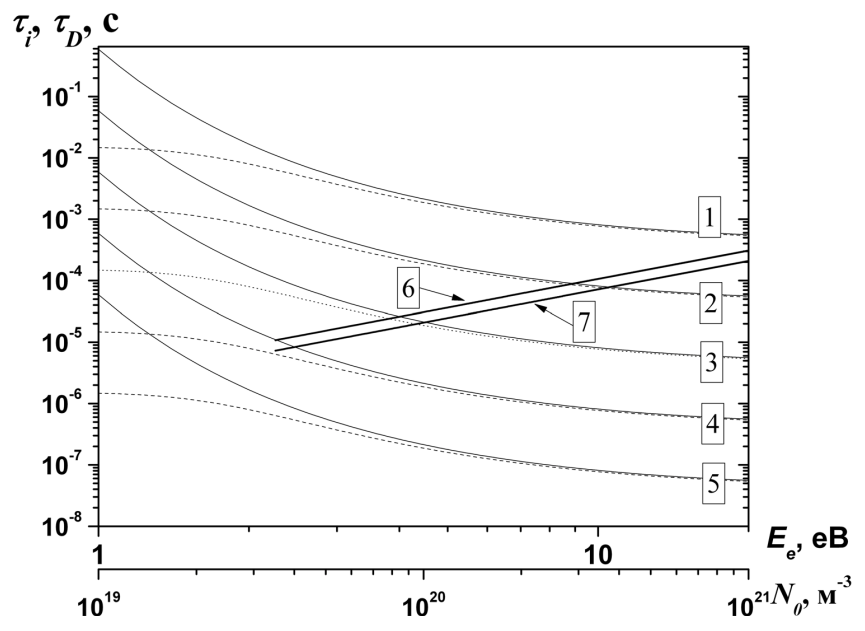

Рис. 6. Залежність часу іонізації атомів титану від енергії електронів (криві 1-5) для різної електронної щільності і часу дифузії атомів титану (криві 6, 7) для різних кутів падіння від початкової густини нейтральних частинок робочої речовини в газовій фазі: $1-10^{16} \mathrm{M}^{-3}, 2-10^{17} \mathrm{M}^{-3}, 3-10^{18} \mathrm{M}^{-3}, 4-$ $10^{19} \mathrm{~m}^{-3}, 5-10^{20} \mathrm{~m}^{-3}, 6-\theta=73^{\circ}, 7-\theta=0^{\circ}$ з урахуванням перезарядки (штрихпунктирні лініi) і без урахування (суцільні лінії)

процесу $k_{\mathrm{PI}}=2,75 \cdot 10^{-16} \mathrm{~m}^{3} / \mathrm{c}$. Таким чином, повний час іонізації з урахуванням додаткових процесів дорівнюе:

$\tau_{i}=\frac{1}{N_{e}\left\langle\sigma_{e} v_{e}\right\rangle+N_{i} k_{\mathrm{CT}}+N_{m} k_{\mathrm{PI}}}, \mathrm{c}$.

Як було показано в [29], пеннінгова іонізація домінує над іонізацією електронами в області густини $\leq 2 \cdot 10^{16} \mathrm{M}^{-3}$ і низьких температур, тому для вищої густини їі можна не враховувати. На рис. 6 наведено залежності часу іонізації атомів титану для різної початкової густини електронів з урахуванням нерезонансної перезарядки і без її врахування (приймаючи $N_{e}=N_{i}$ ). Як видно (див. рис. 6), внесок перезарядки стає істотним лише при Те $\leq 3 \mathrm{eB}$. Зіставлення характерних часів $\tau_{i}$ i $\tau_{D}$ (див. рис. 6) дає тільки якісну картину впливу процесів іонізації і дифузії розпорошених атомів, але не дозволяє дати кількісної оцінки ступеня іонізації розпорошених атомів. У стаціонарному випадку рівняння балансу частинок у плазмі, коли іонізація електронами є основним процесом іонізації, можна записати так:

$$
\begin{aligned}
& \left\langle\sigma_{e} v_{e}\right\rangle N_{e} N_{\mathrm{Ti}}=\frac{N_{\mathrm{Ti}^{+}}}{\tau_{\mathrm{Ti}^{+}}}, \\
& \left\langle\sigma_{e} v_{e}\right\rangle N_{e} N_{\mathrm{Ar}}=\frac{N_{\mathrm{Ar}^{+}}}{\tau_{\mathrm{Ar}^{+}}},
\end{aligned}
$$




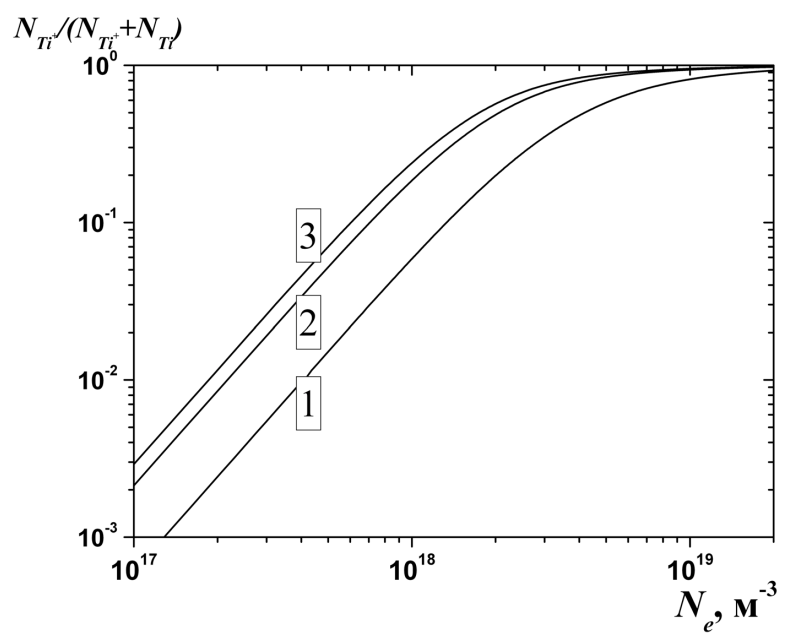

Рис. 7. Залежність ступеня іонізації атомів титану від електронної густини: $1-T_{e}=3 \mathrm{eB} ; 2-T_{e}=6 \mathrm{eB} ; 3-T_{e}=$ $8 \mathrm{eB}$

$N_{e}=N_{\mathrm{Ar}^{+}}+N_{\mathrm{Ti}^{+}}$

де $N_{\mathrm{Ti}}$ і $N_{\mathrm{Ar}}$ - густина нейтральних атомів титану та аргону; $N_{\mathrm{Ti}^{+}}$i $N_{\mathrm{Ar}^{+}}$- густина іонів титану і аргону; $\tau_{\mathrm{Ti}^{+}} \mathrm{i} \tau_{\mathrm{Ar}^{+}}-$часи життя іонів у плазмі. Враховуючи (17), ступінь іонізації можна виразити як:

$\frac{N_{\mathrm{Ti}^{+}}}{N_{\mathrm{Ti}}+N_{\mathrm{Ti}^{+}}}=\frac{\left\langle\sigma_{e} v_{e}\right\rangle N_{e} \tau_{\mathrm{Ti}^{+}}}{1+\left\langle\sigma_{e} v_{e}\right\rangle N_{e} \tau_{\mathrm{Ti}^{+}}}$.

Для випадку імпульсного розряду, коли характерні часи утворення плазми менші за час встановлення іонізаційної рівноваги, ступінь іонізації сильно залежатиме від часу існування плазми із заданою густиною. У нашому випадку характерні часи утворення густини $1,4 \cdot 10^{18}$ і $2 \cdot 10^{19} \mathrm{M}^{-3}$, відповідно, дорівнюють 15 мкс і 100 мкс [14]. У загальному випадку для знаходження ступеня іонізації потрібно розв'язати систему диференціальних рівнянь. Зазвичай, на початковій стадії утворення плазми час життя іона більший від часу зростання густини, тобто $\tau>t$, з урахуванням цього запишемо систему рівнянь:

$$
\left\{\begin{array}{l}
\frac{d N_{e}}{d t}=\left\langle\sigma_{e} v_{e}\right\rangle N_{e} N_{\mathrm{Ar}}+\left\langle\sigma_{e} v_{e}\right\rangle N_{e} N_{\mathrm{Ti}} \\
\frac{d N_{\mathrm{Ar}}}{d t}=-\left\langle\sigma_{e} v_{e}\right\rangle N_{e} N_{\mathrm{Ar}}+N_{\mathrm{Ar}^{+}} N_{\mathrm{Ti}} k_{\mathrm{CT}} \\
\frac{d N_{\mathrm{Ar}}+}{d t}=-\left\langle\sigma_{e} v_{e}\right\rangle N_{e} N_{\mathrm{Ar}}-N_{\mathrm{Ar}}+N_{\mathrm{Ti}} k_{\mathrm{CT}} \\
\frac{d N_{\mathrm{Ti}}}{d t}=\frac{\Gamma S_{\Sigma} Y}{V}-\frac{N_{\mathrm{Ti}}}{\tau_{D}}-\left\langle\sigma_{e} v_{e}\right\rangle N_{e} N_{\mathrm{Ti}}-N_{\mathrm{Ar}}+N_{\mathrm{Ti}} k_{\mathrm{CT}} \\
\frac{d N_{\mathrm{Ti}}+}{d t}=\left\langle\sigma_{e} v_{e}\right\rangle N_{e} N_{\mathrm{Ti}}+N_{\mathrm{Ar}}+N_{\mathrm{Ti}} k_{\mathrm{CT}} .
\end{array}\right.
$$

Для числового розв'язку диференціальних рівнянь задамо початкові умови, згідно з експериментальними даними [14]: розрядна напруга $3,5 \mathrm{kB}$, тобто $E \sim$ 2,8 кеВ; коефіцієнти розпилювання згідно з рис. 2 і 3 ; час дифузії атомів титану по рис. 6; зміна електронної густини відповідає експерименту; $N_{\mathrm{Ar}}=7 \cdot 10^{19}$ $\mathrm{M}^{-3} \mathrm{i}$, оскільки $N_{\mathrm{Ar}}>N_{\mathrm{Ti}}$, другим рівнянням у системі (19) нехтуємо. Результати розрахунку ступеня іонізації атомів титану від густини і температури електронів (функція розподілу за енергією передбачається максвелівською) представлені на рис. 7. Як видно, при густині $2 \cdot 10^{19} \mathrm{~m}^{-3}(t \approx 100 \mathrm{мкc})$ ступінь іонізації близький до 100\%. Середній за об'ємом процентний вміст іонів титану залежно від коефіцієнта розпилення знаходиться на рівні від $10 \%$ до $40 \%$.

Як видно з рис. 6 та 7, ефективність утворення газометалевої плазми (або, що те ж саме - введення металевої робочої речовини з подальшою її іонізацією і утворення газометалевої плазми) за рахунок механізму розпилення катодного матеріалу істотно залежить від густини початкової плазми. Найбільша ефективність утворення газометалевої плазми спостерігається при густині електронів $N_{e} \geq 10^{19} \mathrm{M}^{-3}$ (див. рис. 6 та 7). Незважаючи на те, що розрахунки виконано для одного матеріалу катода (титану), для інших металів повинна спостерігатися подібна картина внаслідок близькості потенціалів і перерізу іонізації. Підтвердженням цього є результати, отримані на установці "ERIC" [12], де використовували запалювальні гази Ar i Kr. При $N_{e} \sim 4 \cdot 10^{16}-2 \cdot 10^{17} \mathrm{M}^{-3}$ i $T_{e} \sim 3-6$ еВ вводилися $\mathrm{Ni}, \mathrm{Cu}, \mathrm{Pd}, \mathrm{Gd}$, при цьому ймовірність іонізації розпорошених атомів становила $\sim 4-14 \%$, а відносна концентрація іонів металів у плазмі - 3-17\%.

Запропонована модель може бути застосована на початковій стадії утворення плазми, коли час життя іона більший за час зростання густини, тобто $\tau>t$. У іншому випадку, наприклад, у стаціонарних умовах, треба враховувати час життя іона (див. рівняння (17), (18)), який складається з рекомбінаційного та дифузійного часу. Модель не враховує залежність коефіцієнта розпилення від температури мішені, який істотно збільшується при $T>0,7 T_{m}[17]$, де $T_{m}$ - температура плавлення, а також утворення кластерів із двох і більше атомів при розпиленні мішені. Також існує невизначеність кута падіння іонів на мішень, пов'язана, з одного боку, з початковими умовами на поверхні мішені (рельєфу), з другого - кут падіння визначається рухом іона у схрещеному електричному та магнітному полях до зіткнення з мішенню, при цьому кут падіння може значно відрізнятися від 0 . 
Проте отримані результати знаходяться в задовільній згоді з експериментальними [13-15], але оцінки, зроблені з використанням даної моделі, не можуть вважатися повними та остаточними і вимагають подальшого уточнення моделі відповідно до зміни експериментальних умов.

\section{4. Висновки}

1. Відповідно до поставленої мети вибрана модель кількісної оцінки надходження важкої компоненти, що розпилюється, в розряд. У межах використаної в роботі моделі проведена оцінка параметрів розпилювального механізму, за рахунок дії якого необхідна робоча речовина надходить до розряду. При цьому проведено облік впливу енергії налітаючих іонів для іонно-атомних пар $\mathrm{Ar}^{+} \rightarrow \mathrm{Ti}$ та $\mathrm{Ti}^{+} \rightarrow \mathrm{Ti}$ при нормальному падінні, а також при зміні кута падіння налітаючих іонів на мішень. Отримані розрахунковим шляхом значення коефіцієнта розпилювання знаходяться у задовільній згоді з експериментально визначеними в аналогічних умовах і опублікованими раніше в [15]. Найбільш динамічна зміна величини коефіцієнта розпилювання відбувається при енергії налітаючих іонів $\leq 200 \mathrm{eB}$ і при кутах падіння $40^{\circ}-85^{\circ}$. 2. Для визначення ефективності утворення газометалевої плазми (або що те ж саме - іонізації газометалевої суміші) розраховано залежності середньої енергії атомів титану, що вилітають з мішені, від енергії налітаючих іонів аргону і титану, від тиску аргону в розрядній камері; залежності часу іонізації атомів титану від енергії електронів і часу дифузії атомів від початкової густини нейтральних частинок, а також ступеня іонізації частинок титану від густини електронів. Найбільша ефективність утворення газометалевої плазми спостерігається при густині електронів $N_{e} \geq 10^{19} \mathrm{M}^{-3}$. Отримані результати задовільно узгоджуються з результатами експерименту [13-15], тоді як використана модель вимагає додаткового уточнення при зміні експериментальних умов.

1. F.M. Penning, Physica 4, 71 (1937).

2. М.Д. Габович, Физика и техника плазменных источников ионов (Атомиздат, Москва, 1972).

3. С.П. Бугаев, Ю.Е. Крендель, П.М. Щанин, Электронные пучки большого сечения (Энергоатомиздат, Москва, 1984).

4. Г.Л. Саксаганский, Электрофизические вакуумные насосы (Энергоатомиздат, Москва, 1988).
5. П.Я. Бурченко, Е.Д. Волков, Ю.А. Грибанов и др., ЖТФ 55, 2134 (1985).

6. G.P. Glazunov, A.A. Andreev, D.I. Baron et al., Vopr. At. Nauki Tekhn. Ser. Plazma Fiz. 2, 107 (2005).

7. Г.П. Глазунов, А.А. Андреев, М.Н. Бондаренко и др., Вопросы атомной науки и техники. Серия: Вакуум, чистые материалы, сверхпроводники 4, 88 (2007).

8. Є.І. Скібенко, Ю.В. Ковтун, А.І. Скибенко, В.Б. Юферов, Пат. UА38780 Україна, Опубл. 12.01.2009, Бюл. №1. (2009).

9. А.И. Карчевский, А.И. Лазько, Ю.А. Муромкин и др., ФП 19, 411 (1993).

10. О.Н. Фейгенсон, Автореферат диссертации (СанктПетербург, 2002).

11. Е.И. Скибенко, Ю.В. Ковтун, А.М. Егоров, В.Б. Юферов, Вопросы атомной науки и техники. Серия: Физика радиационных повреждений и радиационное материаловедение 2(72), 141 (2011).

12. A. Compant La Fontaine and P. Louver, Plasma Sources Sci. Technol. 8, 125 (1999).

13. Ю.В. Ковтун, А.И. Скибенко, Е.И. Скибенко и др., Вопросы атомной науки и техники. Серия: Плазменная электроника и новые методы ускорения 4(68), 214 (2010).

14. Ю.В. Ковтун, А.І. Скибенко, Є.І. Скібенко та ін., УФЖ 55, 1269 (2010).

15. E.I. Skibenko, Yu.V. Kovtun, A.I. Skibenko et al., Techn. Phys. 56, 623 (2011).

16. В.А. Саєнко, В.А. Рудніцький, А.Г. Борисенко, УФЖ 43, 1238 (1998).

17. Энииклопедия низкотемпературной плазмь, под редакцией В.Е. Фортова (Наука, Москва, 2000), Т. 3.

18. Y. Yamamura and H. Tawara, At. Data Nucl. Data Tables 62, 149 (1996).

19. Y. Yamamura, Radiat. Effect 80, 57 (1984).

20. Дж. Гиршфельдер, Ч. Кертисс, Р. Берд, Молекулярная теория газов и жидкостей (Иностранная литература, Москва, 1961).

21. А.Г. Жиглинский, В.В. Кучинский, Е.Г. Шейкин, ЖТФ 56, 1719 (1986).

22. K. Meyer, I.K. Schuller, and C.M. Falco, J. Appl. Phys. 52, 5803 (1981). 
23. G. Falcone, Phys. Rev. B 38, 6398 (1988).

24. M.W. Tompson, Phil. Mag. 18, 377 (1968).

25. B.J. Garrison, Nucl. Instrum. Methods B 17, 305 (1986).

26. M.A. Lennon, K.L. Bell, H.B. Gilbody et al., J. Phys. Chem. Ref. Data. 17, 1285 (1988).

27. Дж. Хастед, Физика атомнъх столкновений (Мир, Москва, 1965).

28. A. Bogaerts, K.A. Temelkov, N.K. Vuchkov, and R. Gijbels, Spectrochim. Acta B 62, 325 (2007).

29. J. Hopwood and F. Qian, J. Appl. Phys. 78, 758 (1995).

Одержано 22.09.11

ОЦЕНКА ЭФФЕКТИВНОСТИ ВВОДА

ВЕЩЕСТВА В ОТРАЖЕННЫЙ РАЗРЯД

ЗА СЧЕТ РАСПЫЛЕНИЯ МАТЕРИАЛА КАТОДА

Ю.В. Ковтун, А.И. Скибенко, Е.И. Скибенко,

В.Б. Юферов

$\mathrm{P}$ е $з$ ю м е

В работе проведено рассмотрение процессов ввода рабочего вещества за счет распылительного механизма и его ионизации в плазме импульсного отраженного разряда на начальной стадии образования плотной газометаллической плазмы. При этом предложена расчетная модель оценки параметров распылительного механизма, за счет действия которого требуемое рабочее вещество поступает в разряд. Полученные данные удовлетворительно согласуются с результатами эксперимента.

\section{ESTIMATION OF THE EFFICIENCY OF MATERIAL} INJECTION INTO THE REFLEX DISCHARGE BY SPUTTERING THE CATHODE MATERIAL

Yu.V. Kovtun, A.I. Skibenko, E.I. Skibenko, V.B. Yuferov

National Science Center

"Kharkov Institute of Physics and Technology", Nat. Acad. of Sci. of Ukraine

(1, Akademichna Str., Kahrkiv 61108, Ukraine; e-mail: Ykovtun@kipt.kharkov.ua)

$\mathrm{S} u \mathrm{~mm}$ a r y

The processes of injection of a sputtered-and-ionized working material into the pulsed reflex discharge plasma have been considered at the initial stage of dense gas-metal plasma formation. A calculation model has been proposed to estimate the parameters of the sputtering mechanism for the required working material to be injected into the discharge. The data obtained are in good accordance with experimental results. 